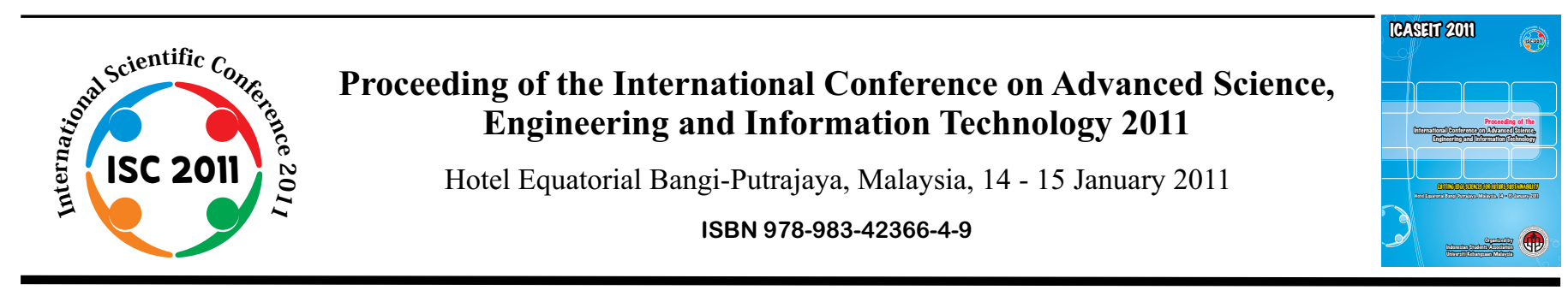

\title{
APTI of Some Selected Plants in Shivamogga City, South Asia
}

\author{
Adamsab M. P*, Hina Kousar ${ }^{\#}$, Shwetha D. S ${ }^{\#}$, Sirajuddin M. H*, Ravichandran M* \\ ${ }^{\#}$ Department of Post Graduate Studies and Research in Environmental Science, Kuvempu University, Jnana Sahyadri, \\ Shankaraghatta-577451, Shivamogga District, Karnataka, India
}

E-mail:ecoadams@yahoo.com

*Department of Environmental Management, School of Environmental Sciences, Bharathidasan University, Tiruchirappalli - 620 024. Tamil Nadu. India

\begin{abstract}
Air pollution is the human introduction into the atmosphere of chemicals, particulate matter or biological materials that cause harm or discomfort to humans or other living organism or damage the environment The study examined air pollution indices (APTI) of fourteen plant species around Shivamogga city of Karnataka State India .Four physiological and biochemical parameters, leaf relative water content (RWC), ascorbic acid (AA), total leaf chlorophyll (TCH), and leaf extract ${ }_{\mathrm{p}} \mathrm{H}$ were used to compute the APTI values.The result showed that combining variety of these parameters gave more reliable result than those of individual parameter.The order of tolerance is as follows: Azadirachta indica, (37.74) Mangifera indica, (28.4) Eucalyptus mysoresins (27.93), Carica papaya(24.62), Ricinus communis (22.46), Polyalthia longifolia(20.76), Calotropis gigantean(19.84), Nerium indicum (18.49), Psidium guajava (17.51), Parthenium hysterophorus (14.91), Bougainvillea glabra (13.35), Muntingia calabura (11.68), Terminalia cattapa (10.71) and Tamarindus indica (9.12).
\end{abstract}

Key words -Air pollution indices (APTI), ascorbic acid (AA), total leaf chlorophyll (TCH), Shivamogga city.

\section{INTRODUCTION}

All combustion releases gases and particles in to the air. These can include sulphur and nitrogen oxides, carbon monoxide and soot particles, as well as smaller quantities of toxic metals, organic molecules and radioactive isotopes .Air pollution is a major problem arising mainly from industrialization [1]. Air pollution can directly affect plants via leaves or indirectly via soil acidification [2]. It has also been reported that when exposed to air pollutants, most plants experience physiological changes before exhibiting visible damage to leaves [3].Several contributors agree that air pollutants affect plant growth adversely $[4,5,6]$. The aim of this study is to determine the air pollution tolerance index of fourteen plant species in Shivamogga city of Karnataka state ,India. 


\section{MATERIALS AND METHODS}

Shivamogga is one of the most important city of Karnataka State and is situated on the banks of river Tunga and spread over an area of $50 \mathrm{~km}^{2}$ (19.31 square miles) with a total population of 474,105 (during 2007) The geographical location of the city is $3^{0} 55^{\prime} 18^{\prime}, \mathrm{N}$, 75'34'12' E. Its height is $584 \mathrm{~m}$ above MSL (Mean Sea Level). It is a blend of history and tradition and a thriving commercial city. It is exposed to southwest monsoon. Humidity is more during the month of July (78\%). The annual rainfall is $200.97 \mathrm{~mm}$ and the average wind velocity is $9.7 \mathrm{~km} / \mathrm{h}$ from southwest. The studies were conducted based on location, population, regional background and other such

\section{METHODOLOGY}

\section{APTI Assessment}

a. Relative Leaf Water Content (RWC)

RWC was determined and calculated with the formula as described by Singh (1977),

Where,

$$
\mathrm{RWC}=\frac{(\mathrm{FW}-\mathrm{DW})}{(\mathrm{TW}-\mathrm{DW})} \times 100
$$

$\mathrm{FW}=$ Fresh weight

DW= Dry weight

\section{b. Total Chlorophyll Content (TCh)}

This was carried out according to the method described by Arnon (1949). $3 \mathrm{gm}$ of fresh leaves were blended and then extracted with $10 \mathrm{ml}$ of $80 \%$ acetone and left for $15 \mathrm{~min}$. The liquid portion was decanted into another test tube and centrifuged at 2,500 rpm for $3 \mathrm{~min}$. The supernatant was collected and the absorbance was then taken at $645 \mathrm{~nm}$ and 663 $\mathrm{nm}$ using a spectrophotometer. Calculations were done by using the formula given below:

\section{c. Leaf Extract using pH Tester}

$5 \mathrm{gm}$ of fresh leaves were homogenized in $10 \mathrm{ml}$ deionised water. This was filtered and the $\mathrm{pH}$ of the leaf extract

\section{d. Ascorbic acid (AA) content}

Ascorbic acid contents were determined by the method of Aberg (1958) and Sadasivam and Manickam (1997).

$5 \mathrm{ml}$ of the working standard solution was pipette out in to a 100 $\mathrm{ml}$ conical flask and $10 \mathrm{ml}$ of $4 \%$ oxalic acid was added and titrated against the dye $\left(\mathrm{V}_{1} \mathrm{ml}\right)$. End point is the appearance of pink color which persists for a few minutes. The amount of the dye consumed is equivalent to the amount of ascorbic acid.

After extracting the sample $(0.5-5 \mathrm{gm}$ depending on the sample) in $4 \%$ oxalic acid, the volume was made up to a known volume and centrifuged. $5 \mathrm{ml}$ of this supernatant was taken in the conical flask and $10 \mathrm{ml}$ of $4 \%$ oxalic acid was added and titrated against the dye $\left(\mathrm{V}_{2} \mathrm{ml}\right)$.

\section{Calculation of APTI:}

The air pollution tolerance index (APTI) was computed by the method suggested by Singh and Rao (1983) using the equation,

$$
\mathrm{APTI}=\frac{[\mathrm{A}(\mathrm{T}+\mathrm{P})+\mathrm{R}]}{10}
$$

factors .The study area was classified into two zones, control site and experimental site. The control site leaf samples were collected from Kuvempu University (premises of Shankarmattha temple) where there is no disturbance of any kind and is relatively unpolluted. Similarly, plant species were collected randomly from experimental site i.e. Shivamogga city. The collected leaf samples were immediately brought to the lab in a heatproof container. The leaf fresh weight was taken immediately upon getting to the laboratory, and then samples were preserved in refrigerator for further analysis.

TW= Turgid weight

Fresh weight was obtained by weighing the leaves. The leaf samples were then immersed in water overnight blotted dry and then weighed to get the turgid weight. The leaves were then dried overnight in a hot air oven at $70^{\circ} \mathrm{C}$ and reweighed to obtain the dry weight.

Chlorophyll a $=12.7 \mathrm{Dx} 663-2.69 \mathrm{DX} 645 * \mathrm{~V} / 1000 \mathrm{~W} \mathrm{mg} / \mathrm{gm}$ Chlorophyll b $=22.9$ Dx $645-4.68$ DX663*V/1000W mg/gm

$\mathrm{TCH}=$ Chlorophyll $\mathrm{a}+\mathrm{b} \mathrm{mg} / \mathrm{gm}$

Where,

$\mathrm{Dx}=$ absorbance of the extract at the wavelength Xnm

$\mathrm{V}=$ Total volume of the chlorophyll solution $(\mathrm{ml})$

$\mathrm{W}=$ Weight of the tissue extracted $(\mathrm{g})$

determined after calibrating $\mathrm{pH}$-meter with buffer solution of pH 4 and 9.

Amount of ascorbic acid mg/100 gm sample was calculated by,

$$
\text { Ascorbic acid }=\frac{\left[0.5 \mathrm{mg} / \mathrm{V}_{\mathbf{1}} \mathrm{ml} * \mathrm{~V}_{\mathbf{2}} / 5 \mathrm{ml} * 100 \mathrm{ml}\right.}{\text { wt. of sample }]} \times 100
$$

Where,

$\mathrm{A}=$ Ascorbic acid content $(\mathrm{mg} / \mathrm{gm})$

$\mathrm{T}=$ Total Chlorophyll $(\mathrm{mg} / \mathrm{gm})$

$\mathrm{P}=\mathrm{pH}$ of the leaf extract

$\mathrm{R}=$ Relative water content of leaf $(\%)$ 


\section{RESULT AND DISCUSSION}

Table 1: Air pollution tolerance index (APTI) of plant species growing in experimental site. (Shivamogga)

\begin{tabular}{|c|l|c|c|c|c|c|}
\hline SI .No. & \multicolumn{1}{|c|}{ PLANT SPECIES } & RWC & TCH & pH & AA & APTI \\
\hline 1 & Carica papaya & 86.04 & 0.79 & 6 & 23.6 & 24.62 \\
\hline 2 & Calotropis gigantea & 61.22 & 0.76 & 6.5 & 18.9 & 19.84 \\
\hline 3 & Eucalyptus mysoresins & 85.71 & 0.25 & 5.6 & 33.1 & 27.93 \\
\hline 4 & Parthenium hysterophorus & 79.1 & 0.51 & 6.9 & 9.45 & 14.91 \\
\hline 5 & Nerium indicum & 84.37 & 0.93 & 6.2 & 14.1 & 18.49 \\
\hline 6 & Polyalthia longifola & 87.8 & 0.24 & 6.1 & 18.9 & 20.76 \\
\hline 7 & Mangifera indica & 90.9 & 0.51 & 4.6 & 37.8 & 28.4 \\
\hline 8 & Ricinus communis & 89.7 & 1.24 & 5.9 & 18.9 & 22.46 \\
\hline 9 & Psidum guajava & 77.14 & 1.25 & 5.7 & 14.1 & 17.51 \\
\hline 10 & Mutangia calibra & 59.25 & 0.39 & 5.7 & 9.45 & 11.68 \\
\hline 11 & Bougainvillea glabra & 69.56 & 1.17 & 5.6 & 9.45 & 13.35 \\
\hline 12 & Terminalia cattapa & 83.72 & 0.47 & 4.5 & 4.72 & 10.71 \\
\hline 13 & Azadirachta indica & 91.92 & 0.15 & 5.9 & 47.2 & 37.74 \\
\hline 14 & Tamarindus indica & 50.9 & 0.07 & 4.2 & 9.45 & 9.12 \\
\hline
\end{tabular}

RWC $=$ Relative water content

$\mathrm{TCH}=$ Total Chlorophyll content

$\mathrm{AA}=$ Ascorbic acid

APTI $=$ Air Pollution tolerance index

Table.2: Air pollution tolerance index (APTI) of plant species growing in control site Kuvempu University (premises of Shankarmattha temple)

\begin{tabular}{|c|l|c|c|c|c|c|}
\hline SL.NO. & \multicolumn{1}{|c|}{ PLANT SPECIES } & RWC & TCH & pH & AA & APTI \\
\hline 1 & Carica papaya & 71.09 & 0.6 & 6.2 & 18.91 & 19.96 \\
\hline 2 & Calotropis gigantea & 57.8 & 0.18 & 5.7 & 14.18 & 14.11 \\
\hline 3 & Eucalyptus mysoresins & 75.54 & 0.13 & 5.2 & 28.3 & 22.63 \\
\hline 4 & Parthenium hysterophorus & 77.92 & 0.38 & 6.7 & 4.72 & 11.13 \\
\hline 5 & Nerium indicum & 78.63 & 0.06 & 5.8 & 9.45 & 13.4 \\
\hline 6 & Polyalthia longifola & 79.59 & 0.2 & 5.9 & 14.18 & 16.6 \\
\hline 7 & Mangifera indica & 53.14 & 0.15 & 4.5 & 33.1 & 20.7 \\
\hline 8 & Ricinus communis & 75.04 & 0.18 & 5.7 & 14.18 & 15.84 \\
\hline 9 & Psidum guajava & 74.32 & 0.67 & 4.9 & 9.45 & 12.69 \\
\hline 10 & Mutangia calibra & 41.88 & 0.15 & 5.5 & 4.72 & 6.85 \\
\hline 11 & Bougainvillea glabra & 65.85 & 0.06 & 5.4 & 4.72 & 9.16 \\
\hline 12 & Terminalia cattapa & 70.29 & 0.29 & 4.2 & 4.72 & 9.14 \\
\hline 13 & Azadirachta indica & 77.29 & 0.15 & 5.6 & 37.8 & 29.46 \\
\hline 14 & Tamarindus indica & 44.94 & 0.07 & 3.2 & 4.72 & 6.03 \\
\hline
\end{tabular}

RWC $=$ Relative water content

$\mathrm{TCH}=$ Total Chlorophyll content

$\mathrm{AA}=$ Ascorbic acid

APTI $=$ Air Pollution tolerance index

From the present study it is evident that out of the 14 species studied, Azadirachta indica (37.74) has high APTI value in the experimental site(Table 1) and is most tolerant among all fourteen, followed by Mangifera indica, (28.4) Eucalyptus mysoresins (27.93), Carica papaya(24.62), Ricinus communis (22.46), Polyalthia longifolia(20.76), Calotropis gigantean(19.84), Nerium indicum (18.49), Psidium guajava (17.51), Parthenium hysterophorus (14.91), Bougainvillea glabra (13.35), Muntingia calabura (11.68), Terminalia cattapa (10.71) and Tamarindus indica (9.12).

A similar work has been carried out by [7] who have worked on ten plant species around the Erhoike- kokori oil exploration station of Delta State. The APTI values of plant species growing in control site is given in the (Table 2). High APTI values are reported in the species Azadirachta indica (29.46), Eucalyptus mysoresins (22.63), Carica papaya (19.96) Polyalthia longifolia (16.6), Ricinus communis (15.84) and Calotropis gigantean (14.11). The APTI values of remaining species ranged from (13.4 to 6.03). 


\section{CONCLUSION}

Air Pollution Tolerance Index determination is of utmost importance because with increased vehicular movements, urbanization and a rapid increase in small scale industries the pollution load is on the rise. The results of such studies are helpful for future planning. Vegetation naturally cleanses the atmosphere by absorbing gases and some particulate matter through leaves. Plants have a very large surface area and their leaves function as an efficient pollutant-trapping device. Some plants have been classified according to their degree of sensitivity and tolerance towards various air pollutants. Sensitive plant species are suggested to act as

\section{ACKNOWLEDGEMENT}

Our sincere thanks to Dr. T. Ravi Mycin, Department of Botany, Annamalai University, Annamalainagar, Tamil Nadu.for this kind co-operation during this work.

\section{REFERENCES}

[1] C.A. Odilara, P.A, Egwaikhide, A. Esekheigbe, S.A.Emua, "Air pollution Tolerance Indices (APTI) of some plant species around llupeju Industrial Area, Lagos'Journal of Engineering Science and Applications 4 (2)97- 101, 2006.

[2] L. Steubing, A. Fangmier, R. Both, " Effects of SO2, NO2, and O3 on Population Development and Morphological and Physiological parameters of Native Herb Layer Species in a Beech Forest', Environmental pollution 58:281-302, 1989.

[3] G.P.Dohmen,A.Loppers,C. Langebartels, Biochemical Response of Norway Spruce (Picea Abies (L) Karst) Toward 14-Month Exposure to Titers. Environmental pollution 64:375-383.1990. bio-indicators. Levels of air pollution tolerance vary from species to species, depending on the capacity of plants to withstand the effect of pollutants without showing any external damage. In this study, the air pollution tolerance index (APTI) of 14 plant species has been evaluated. High values of APTI were recorded in Azadirachta indica, Mangifera indica, Eucalyptus mysoresins, and Carica papaya, Ricinus communis, Polyalthia longifolia, Calotropis gigantean, Nerium indicum, Psidium guajava, Parthenium hysterophorus, Bougainvillea glabra, Muntingia calabura, Terminalia cattapa, Tamarindus indica.
[4] C.S.Rao Environmental pollution control Engineering, Revised Second Edition, New Age International Publishers. Delhi, 2006.

[5] S.C.Bhatia, Environmental Chemistry CBS Publishers and Distributors .New Delhi, 2006.

[6] G.S.Sodhi, Fundamental concepts of Environmental chemistry Second Edition. Narosa Publisher and Distributors. Delhi 2005

[7] P.O. Agbaire, E. Esiefarienrhe Air Pollution tolerance indices (apti) of some plants around Otorogun Gas Plant in Delta State, Nigeria. Journal of Appl. Sci. Environment Management Vol.13(1) 11 - 14, 2009. 